\title{
Ethical implications of shared decision-making in Parkinson's disease treatment
}

\author{
Ingrid Estrada-Bellmann ${ }^{1 *}$ and Jesús D. Meléndez-Flores ${ }^{2}$ \\ ${ }^{1}$ Department of Internal Medicine, Movement Disorders Clinic, Neurology Division, University Hospital “Dr. José E. González"; ${ }^{2}$ Faculty of Medicine. \\ Universidad Autónoma de Nuevo León, Nuevo León, Monterrey, Mexico
}

\begin{abstract}
Shared decision-making (SDM) involves an active participation of the patient in deciding treatment choice, based on his/her preferences, beliefs, and values. In the context of Parkinson's disease (PD), physicians encounter limitations in applying this model related to cognitive decline and other disease-related complications. Discussing the ethics of this approach on the context of these limitations the PD patient suffers is thus of great importance. This review intends to analyze ethical challenges of SDM in PD related to decision-making capacity, surrogates' role in patient's identity, and patients' and physicians' preferences. Although skepticism could arise when dealing with surrogates' decisions, a key for flourishing the patient's autonomy is acknowledging its relational context, as relatives' beliefs and values are imprinted in the patient's identity. To do so, empathy should be encouraged in physicians, recognizing the different value attribution that patients and their relatives have in the decision process.
\end{abstract}

Key word: Cognition. Parkinson disease. Shared decision-making. Surrogate decision maker.

\section{Implicaciones éticas de la toma de decisiones compartida en el tratamiento de la enfermedad de Parkinson}

\section{Resumen}

La toma de decisiones compartida (TDC) implica una participación activa del paciente en la decisión del tratamiento, en función de sus preferencias, creencias y valores. En el contexto de la enfermedad de Parkinson (EP), los médicos encuentran limitaciones al aplicar este modelo relacionado con el deterioro cognitivo y otras complicaciones relacionadas con la enfermedad. Discutir la ética de este enfoque en el contexto de estas limitaciones que sufre el paciente con EP es, por lo tanto, de gran importancia. Esta revisión tiene la intención de analizar los desafíos éticos de la TDC en la EP relacionados con la capacidad de toma de decisiones, el rol del tomador de decisiones sustituto en la identidad del paciente y las preferencias de los pacientes y médicos. Aunque podría surgir escepticismo al tratar con las decisiones de los sustitutos, una clave para el florecimiento de la autonomía del paciente es reconocer su contexto relacional, ya que las creencias y valores de los familiares están impresos en la identidad del paciente. Para hacerlo, se debe alentar la empatía en los médicos, or recono-ciendo la diferente atribución de valor que los pacientes y sus familiares tienen en el proceso de decisión.

Palabras clave: Cognición. Enfermedad de Parkinson. Toma de decisiones compartida. Tomador de decisiones sustituto.

Correspondence:

*Ingrid Estrada-Bellmann

E-mail: ingridestmann @ hotmail.com
Available online: $30-11-2020$ Rev Mex Neuroci. 2020;21(6):235-239 www.revmexneurociencia.com 1665-5044/ @ 2020. Academia Mexicana de Neurología A.C. Published by Permanyer. This is an open access article under the CC BY-NC-ND license (http://creativecommons.org/licenses/by-nc-nd/4.0/). 


\section{Introduction}

Shared decision-making (SDM) has been a topic broadly discussed in medicine, where ultimately the shift from paternalistic toward more patient-centered care is being more encouraged. The ideal of SDM involves patients and physicians discussing treatment options based on patients' values, beliefs, and preferences, reaching a consensual decision ${ }^{1,2}$. The ethical guidelines of this approach rely on the principles of bioethics: patient's autonomy, beneficence, non-maleficence, and justice. In the neurology field, especially Parkinson's disease (PD), physicians encounter limitations when trying to apply this approach, this related to the cognitive decline and other complications that most PD patients suffer in advanced stages ${ }^{3}$. This leads to physicians questioning SDM applicability in reassuring what is best for the patient, tending to revert to a paternalistic approach ${ }^{4}$.

This review aims to analyze ethical challenges related to SDM in the context of PD patients through analysis of decision-making capacity, autonomy, and surrogates, and medical and patients' preferences in the treatment context.

\section{Decision-making capacity in PD patients: an obstacle for SDM}

For a decision to be made, this must have been consent. This implies that patients had to be informed, choose voluntary, and had the competence to decide 5 . Problems arise with the population suffering neurodegenerative diseases, such as Alzheimer's and PD, as the cognitive decline over years makes physicians question their decision-making capacity. In fact, studies evaluating this capacity in PD patients with cognitive impairment have found that, compared to controls, this population has deficits in this decision-making process $^{3,6-10}$. Furthermore, within this capacity, domains affected mostly are understanding, reasoning, and appreciation, but no differences arise from choice ${ }^{8,11}$. This means that a patient later on advanced stages could express a decision that is against his former way of reasoning and be additionally detrimental, thus making the physician, who has followed him/her along the progression of the disease, question, and put aside his/ her preferences and consider weighing the principle of non-maleficence over autonomy.

On the other side, a study on non-demented nor cognitive impaired PD patients showed no differences in decision capacity compared to healthy controls ${ }^{12}$.
The main problem regarding this study lies on the prevalence of cognitive impairment in newly diagnosed PD patients, which is over $20 \%{ }^{13}$. Hence, to ensure SDM in all stages of the disease, this implies the ethical need of awareness and screening for decision capacity in patients even at the first stages of the disease. Moreover, as the cognitive decline in PD follows a progressive course ${ }^{14,15}$, focus has been attributed on determining the existence of a window period of maximum decision capacity ${ }^{16}$. This is critical in the SDM process as this period can be used for (1) the physician to get to know the patients' preferences, values, and beliefs related to treatment and (2) the family could be educated in the process of becoming a surrogate decision-maker alongside patient and physicians to ensure preferences are aligned.

PD patients with cognitive impairment or dementia suffer problems in understanding, reasoning, and appreciation areas of decision capacity. However, not all decisions are based on reasoning or logic. Some are made by applying values, emotions, needs, and habits $^{17,18}$. Moreover, critics on the traditional approach of decision capacity assessment argue that this is more cognitive based, whereas emotional factors are left aside $^{19-21}$. This has ethical considerations, as emotions and values are basic for human experience and for the acquisition of knowledge ${ }^{22}$, so a question arises: is it ethical to accept a cognitive impaired PD patient's decision when this is based only on values or emotions? As these non-cognitive factors form part of the patient's identity, if the non-maleficence principle is not infringed, autonomy principle must be respected. Nonetheless, this has two considerations (1) this might collide with what the physician thinks is best for the patient (beneficence principle). Here is where SDM and physicians' empathy toward patients' values comes into play, as this increases participation ${ }^{23}$, and acknowledges differences in value attributions. Moreover, (2) as the patient is a social being, his/her identity is influenced by his interactions with others, implicating a role of a third party in the decision-making process.

\section{Surrogate decision-making in advanced PD: the role of the third party}

As the disease progresses, and PD patients are incompetent to decide for themselves, the individual approach to autonomy urges for advance care directives to be implemented ${ }^{24,25}$, where explicit patient wishes are heard and taken into consideration, and no interference of third parties is desired. However, problems arise with 
this approach. Only a few percentage of patients undertake these directives ${ }^{26}$, and it may seem impossible to foresee all the possible clinical scenarios in practice ${ }^{27}$. Moreover, a patient's literal statement may be vague or prompt to different interpretations from relatives or physicians ${ }^{28}$. Nonetheless, the main problem with this viewpoint of autonomy is that it views a patient as an isolated individual making an isolated decision, when he/she forms part of a social context, where interactions and interdependency with others are inevitable. Thus, surrogate decision-makers come into play, keeping PD patient's preferences at the center of the process.

When contemplating the patient as a social being, his/her identity is thus seen as being influenced by others in a social trade-off. In this manner, the society's and family's values, beliefs, and preferences are imprinted in this identity. Van Nistelrooij et al. expressed this view as relatives being coeditors of the patient's identity, shifting the concept of autonomy to a relational context $^{29}$. Consequently, choices regarding health problems are not to be seen as individual, but rather involving the help of the third parties, as these may aid the patient in showing an insight into his/her past, and present, being thus part of the decision-making pro$\operatorname{cess}^{25,30}$. Following this logic, surrogate decision-makers, when being close relatives to the patient, constitute a door to patient's values and preferences, making a substituted judgment. However, a systematic review on accuracy of surrogates' decisions showed that these incorrectly predict patient's preferences in one-third of cases $^{31}$. Furthermore, another study showed that surrogates rely on other factors such as their best interest or mutual interest ${ }^{32}$, making physicians question the validity of the decision taken by these substitutes.

Nonetheless, a study showed that patients, when being unable to decide for themselves, weighed more heavily the loved ones' input than physicians' input ${ }^{33}$. This could be understood as patients acknowledging relatives' influence on their decision, as they share mutual interests, values, and beliefs. In fact, some articles share the idea that one's personal interests are not only self-centered, but other's centered ${ }^{34-37}$, adapting preferences according to intimates' wishes ${ }^{38}$. Rather than seeing this as a threat to the intrinsic value of autonomy, physicians should be aware of the relational context of this concept and aid surrogates on taking the best decision for the patient, pledging at all time to the beneficence principle. This implies that the decision, instead of being delegated completely to the family, is being shared by physicians and the latter, in a substituted interests model ${ }^{39}$, where the clinical expertise and experience of the physicians, along with the knowledge of the PD patient's values and preferences from the surrogates' viewpoint, aid define the particular interests of the patient in a particular clinical scenario, fulfilling the patient's full autonomy and fulfilling the beneficence principle. Sharing this decision implies from an ethical view that medical judgment reassures all bioethical principles are being considered, while relieving the emotional burden that surrogates may experience.

\section{Physicians and patients' preferences: the need for empathy}

As new treatment modalities arise in $\mathrm{PD}$, a physician might feel necessary to change to device-aided therapeutics, such as deep brain stimulation, subcutaneous apomorphine pump, or levodopa-carbidopa intestinal gel infusion, to improve motor or non-motor function, weighing harms, and benefits for their implementation. However, physicians may weigh these differently compared to patients ${ }^{40}$, and their pledge toward maximizing benefit might impede listening what patients really want. A study showed that some PD patients focused more on optimizing the process of care, while others focused on improving motor symptoms ${ }^{41}$. Furthermore, another study concluded that PD patients might not want to undergo advanced treatments to obtain health improvements, as they might feel adapted to their current situation $^{42}$. The latter could surprise physicians, and these could be prompted to question this decision, trying to convince patients of a specific treatment based on potential benefits, tending to an unwarranted paternalistic approach. The key to change this urge of paternalism dressed in the physician's mind as beneficence is empathy. That is, in the SDM process, the physician should try to understand what the patient wants and what is more important for him/her based on his/her needs, placing his/her autonomy, in a relational context as discussed previously, as central for the decision process. Moreover, involving the patient in the decision-making process goes beyond ethical issues, as a study showed that PD patients who are involved have more treatment adherence ${ }^{43}$. In this manner, interventions aimed at assessing and improving empathy process should be implemented not only in neurological residencies, but rather in all medical residency programs throughout all years, as a study showed that self-evaluated empathy in medical residents declines at the end of their training programs ${ }^{44}$. By implementing educational programs that have proven useful in increasing empathy levels among medical residents and students ${ }^{45,46}$, the formation of 
future specialists that acknowledge the need of placing the patient's preferences, needs, and interests on the front line could be reassured.

\section{Conclusion}

From the diagnosis and first encounter of a PD patient, assessing his or her decision capacity must be an ethical imperative for physicians, as in SDM, patient's preferences are determining in modeling the conduct physicians would take for future encounters. That being said, medical judgments and patients' preferences are not two opposing poles, where the physician calls on his/her expertise and experience, and questions decisions that diverge from his/her viewpoint, as this is implicitly an act of paternalism that leaves the patient's autonomy aside. Rather, through empathy, these two should align toward the same direction from the first encounter, as this goes beyond ethical manners, improving quality of patient care. Moreover, in PD, as the patient's decision capacity decreases, the inclusion of family members as surrogates is vital, as they provide an insight into the patient's preferences, beliefs, and interests, being part of the patient's identity. In this manner, the physicians, bearing into mind the patient's beliefs and preferences, discuss with family members and share their expertise toward what's best for the patient in a circumstance, and by doing so, fulfill the patients' autonomy at all time.

This review proposes that it is not about questioning the patient's autonomy in PD and considering the physicians' judgment as better grounded, but rather, with the help of the family members, promote the understanding of the preferences and interests of the patient, reaching to a shared decision that places autonomy in the center of the decision.

\section{Funding}

This research has not received any specific grant from agencies in the public, commercial, or non-profit sectors.

\section{Conflicts of interest}

None.

\section{Ethical disclosures}

Protection of human and animal subjects. The authors declare that no experiments were performed on humans or animals for this study.
Confidentiality of data. The authors declare that no patient data appear in this article.

Right to privacy and informed consent. The authors declare that no patient data appear in this article.

\section{References}

1. Charles C, Gafni A, Whelan T. Shared decision-making in the medical encounter: what does it mean? (or it takes at least two to tango). Soc Sci Med. 1997;44:681-92.

2. Barry MJ, Edgman-Levitan S. Shared decision making-the pinnacle of patient centered care. N Engl J Med. 2012;366:780-1.

3. Herz DM, Bogacz R, Brown P. Neuroscience: impaired decision-making in Parkinson's disease. Curr Biol. 2016;26:R671-3.

4. Driever EM, Stiggelbout AM, Brand PL. Shared decision making: physicians' preferred role, usual role and their perception of its key components. Patient Educ Couns. 2020;103:77-82.

5. Grisso T, Appelbaum P. Assessing Competence to Consent to Treatment: a Guide for Physicians and Other Health Professionals. New York: Oxford University Press; 1998.

6. Karlawish J, Cary M, Moelter ST, Siderowf A, Sullo E, Xie S, et al. Cognitive impairment and PD patients' capacity to consent to research. Neurology. 2013:81:801-7.

7. Martin RC, Okonkwo OC, Hill J, Griffith HR, Triebel K, Bartolucci A, et al. Medical decision-making capacity in cognitively impaired Parkinson's disease patients without dementia. Mov Disord. 2008;23:1867-74.

8. Griffith HR, Dymek MP, Atchison P, Harrell L, Marson DC. Medical decision-making in neurodegenerative disease: mild $A D$ and $P D$ with cognitive impairment. Neurology. 2005;65:483-5.

9. Brand M, Labudda K, Kalbe E, Hilker R, Emmans D, Fuchs G, et al. Decision-making impairments in patients with Parkinson's disease. Behav Neurol. 2004;15:77-85

10. Dymek MP, Atchison P, Harrell L, Marson DC. Competency to consent to medical treatment in cognitively impaired patients with Parkinson's disease. Neurology. 2000;56:17-24

11. Abu Snineh M, Camicioli R, Miyasaki JM. Decisional capacity for advanced care directives in Parkinson's disease with cognitive concerns. Parkinsonism Relat Disord. 2017;39:77-9.

12. Eygelshoven S, van den Hout A, Tucha L, Fuermaier A, Bangma D, Thome J, et al. Are non-demented patients with Parkinson's disease able to decide about their own treatment? Parkinson Relat Disord. 2017; 38:48-53.

13. Muslimovic D, Post B, Speelman JD, Schmand B. Cognitive profile of patients with newly diagnosed Parkinson disease. Neurology. 2005;65:1239-45.

14. Stepkina DA, Zakharov VV, Yakhno NN. Cognitive impairments in progression of Parkinson's disease. Neurosci Behav Physiol. 2010;40:61-7.

15. Muslimovic D, Post B, Speelman JD, De Haan RJ, Schmand B. Cognitive decline in Parkinson's disease: a prospective longitudinal study. J Int Neuropsychol Soc. 2009;15:426-37.

16. Okonkwo OC, Griffith HR, Copeland JN, Belue K, Lanza S, Zamrini EY, et al. Medical decision-making capacity in mild cognitive impairment: a 3-year longitudinal study. Neurology. 2008;71:1474-80.

17. Mozley CG, Huxley P, Sutcliffe C, Bagley H, Burns A, Challis D, et al. Not knowing where I am doesn't mean I don't know what I like: cognitive impairment and quality of life responses in elderly people. Int J Geriatr Psychiatry. 1999;14:776-83.

18. Karel MJ, Gurrera RJ, Moye H, Moye J. Reasoning in the capacity to make medical decisions: the consideration of values. J Clin Ethics. 2010;21:58-71.

19. Hermann $\mathrm{H}$, Trachsel M, Elger BS, Biller-Andorno N. Emotion and value in the evaluation of medical decision-making capacity: a narrative review of arguments. Front Psychol. 2016;7:765.

20. Charland LC. Is Mr. Spock mentally competent? Competence to consent and emotion. Philos Psychiatr Psychol. 1998b;5:67-81.

21. Banner NF. Can procedural and substantive elements of decision-making be reconciled in assessments of mental capacity? Int J Law Context. 2013:9:71-86.

22. van de Lagemaat R. Theory of Knowledege for the IB Diploma. $2^{\text {nd }}$ ed. Cambridge: Cambridge University Press; 2015.

23. Kirkscey R. Bioethical communication: shared decision-making and relational empathy. J Commun Healthc. 2018;11:164-74.

24. Silveira MJ, Kim SY, Langa KM. Advance directives and outcomes of surrogate decision making before death. N Engl J Med. 2010;362: 1211-8.

25. Donchin A. Understanding autonomy relationally: toward a reconfiguration of bioethical principles. J Med Philos. 2001;26:365-86. 


\section{Estrada-Bellmann, J. D. Meléndez-Flores: Shared decision-making in Parkinson's}

26. Perkins HS. Controlling death: the false promise of advance directives. Ann Intern Med. 2007;147:51-7.

27. Sudore RL, Fried TR. Redefining the planning in advance care planning preparing for end-of-life decision making. Ann Intern Med. 2010;153:256-1.

28. Fagerlin A, Schneider CE. Enough: the failure of the living will. Hastings Cent Rep. 2004;34:30

29. Van Nistelrooij I, Visse M, Spekkink A, de Lange J. How shared is shared decision-making? A care-ethical view on the role of partner and family. $\mathrm{J}$ Med Ethics. 2017;43:637-44.

30. Dove ES, Kelly SE, Lucivero F, Machirori M, Dheensa S, Prainsack B. Beyond individualism: is there a place for relational autonomy in clinical practice and research? Clin Ethics. 2017;12:150-65.

31. Shalowitz DI, Garrett-Mayer E, Wendler D. The accuracy of surrogate decision makers: a systematic review. Arch Intern Med. 2006;166:493-7.

32. Vig EK, Taylor JS, Starks H, Hopley EK, Fryer-Edwards K. Beyond substituted judgment: how surrogates navigate end-of-life decision-making. J Am Geriatr Soc. 2006;54:1688-93.

33. Nolan MT, Hughes M, Narendra DP, Sood JR, Terry PB, Astrow AB, et al. When patients lack capacity: the roles that patients with terminal diagnoses would choose for their physicians and loved ones in making medical decisions. J Pain Symptom Manage. 2005;30:342-53.

34. Ho A. Relational autonomy or undue pressure? Family's role in medical decision-making. Scand J Caring Sci. 2008;22:128-35.

35. Walter JK, Ross LF. Relational autonomy: moving beyond the limits of isolated individualism. Pediatrics. 2014;133:S16-23.

36. Lolich L, Lynch K. No choice without care: palliative care as a relational matter, the case of Ireland. Soundings. 2017;100:353-74.
37. Gómez-Vírseda C, de Maeseneer Y, Gastmans C. Relational autonomy: what does it mean and how is it used in end-of-life care? A systematic review of argument-based ethics literature. BMC Med Ethics. 2019;20:76.

38. Azoulay $\mathrm{E}$, Chaize M, Kentish-Barnes N. Involvement of ICU families in decisions: fine-tuning the partnership. Ann Intensive Care. 2014;4:37.

39. Sulmasy D, Snyder L. Substituted interests and best judgments: an integrated model of surrogate decision making. JAMA. 2010;304:1946-7.

40. Mühlbacher AC, Juhnke C. Patient preferences versus physicians' judgement: does it make a difference in healthcare decision making? Appl Health Econ Health Policy. 2013;11:163-80.

41. Weernink MG, van Til JA, van Vugt JP, Movig KL, Groothuis-Oudshoorn CG IJzerman MJ. Involving patients in weighting benefits and harms of treatment in Parkinson's disease. PLoS One. 2016;11:e0160771.

42. Weernink MG, van Til JA, Groothuis-Oudshoorn CG, IJzerman MJ. Patient and public preferences for treatment attributes in Parkinson's disease. Patient. 2017;10:763-72.

43. Grosset KA, Grosset DG. Patient-perceived involvement and satisfaction in Parkinson's disease: effect on therapy decisions and quality of life. Mov Disord. 2005;20:616-9.

44. Foreback J, Kusz H, Lepisto BL, Pawlaczyk B. Empathy in internal medicine residents at community-based hospitals: a cross-sectional study. J Med Educ Curric Dev. 2018;5:1-4

45. Kelm Z, Womer J, Walter JK, Feudtner C. Interventions to cultivate physician empathy: a systematic review. BMC Med Educ. 2014;14:219.

46. Batt-Rawden SA, Chisolm MS, Anton B, Flickinger TE. Teaching empathy to medical students: an updated, systematic review. Acad Med. 2013; 88:1171-7. 